\title{
The Dynamic of the Role of Volunteer as a Political Communicator: A Descriptive Study on Volunteer's Agus-Sylvi at the Election of the Jakarta Governor 2017
}

\author{
Enjang Pera Irawan \\ Fakultas Ilmu Komunikasi \\ Universitas Mercu Buana \\ Jakarta - Indonesia \\ Email: enjang.irawan [AT] mercubuana.ac.id
}

\begin{abstract}
The dynamic of democracy has been widely open in Indonesia after the reformation was launched in 1998. Nowadays, Indonesian are already politically literate and become political subjects. Based on these conditions, the researcher is interested in conducting research related to the dynamics of the role of volunteer as political communicator in the election of Jakarta governor in 2017. The purpose of this research is to know how the communication dynamics of the volunteers in raising public support in the governor election of Jakarta 2017 using descriptive qualitative as the research method. The results show that the political communication strategy applied by the volunteers of Agus-Sylvi is to prioritize approaches such as: a) Creating togetherness b) making consensus with the community, and c) highlighting the character of $S B Y$ as part of strengthening the character of Agus. The message of political communication Agus-Sylvi volunteers are vision mission and work programs that are delivered and packaged in a rational and emotional message. Political messages are delivered by volunteers through various meetings and dialogues, community service, social service, and casual conversation. Communication media used include conventional communication media such as banners, calendars, $t$-shirts. Then, digital media such as WhatsApp, website and application MataHati. Volunteer communication patterns used are internal coordination activity of volunteer and candidate (implementing vertical and horizontal communication pattern), and activity of message transfer from volunteer to society (implementing formal and informal communication pattern).
\end{abstract}

Keywords---Volunteer, Political Communication, Governor Election, Jakarta

\section{INTRODUCTION}

The gate of democracy is open after the reformation was launched in 1998. As a result of this condition gives a positive impact to the portrait of politics in the country, thus affecting lives in the nation and state. Nowadays, Indonesian have already interested with politically literate and became the subject of politics. This is shown by the recent rise of volunteers in each election to the regions in various cities and provinces in Indonesia. Obviously, this condition gives a new condition for the creation of a participatory development towards the welfare of the people of Indonesia, as the purpose of democracy.

Democracy comes from the word "demos" and "kratos". That is, the pattern of government that comes from the people. It could also be the government (President) elected by the representatives of the people. Meaning, the highest power is in the hands of the citizen. Democracy is developed to foster people's participation, not one's or group's participation. The role of the people (read: the public) is more valued because it plays an important role in making decisions for the public interest. Call it, in determining a Regional Head, Regent, Governor, and President as head of state in the democratic system should be elected by the people (Jailani, 2015).

In order to create democracy system properly, it needs high public participation. However, youth's participation in politic is still being polemic. Young people usually do not aware with political problem and do not have good relationship with political community. They also have low trust to politician, political institution and government (Pirie \& Worcester, 1998; Haste \& Hogan, 2006). These phenomenon could be seen from the data that show young people who participate in political party are low. They also tend to do not choose any party in the election (EACEA, 2012). Although youth's role in political event is important in order to increase proper political system.

Although enthusiasm and public participation in the election was pluctuative, where the number of voter participation in Indonesia since the 1999 to 2009 elections had been decreased. However, since the 2014 Legislative Election, 2014 Presidential Election, until elections 2015, the total number remain in the range of $70 \%$. In these three events, the participation rates were pluctuative. For example, the average participation rate in 264 regions was 70 percent during the election 2015. [Retrieved on 29 March 2017 from http://www.republika.co.id].

When the condition of public political participation has pluctuated, but the trend of political volunteers suddenly had been increased. Many people do not affiliate with political parties, but instead volunteer for their respective top candidates. For example, before the elections of DKI Jakarta, various volunteer communities such as Jokowi volunteer, 
Ahok friend, Anies Sandiaga Uno friend, Agus Sylvi volunteer, Adhyaksa friend, Djarot friend, Democratic Volunteer of KPU, and others.

Participation is important part in democracy, Huntington \& Nelson (1976: 3) said "By political participation we mean activity by private citizens designed to influence government decision-making." According to this definition, political participation means as citizen activities to influence government's decision. Then Dahrendorf (2003) stated "Political participation affords citizens in a democracy an opportunity to communicate information to government officials about their concerns and preferences and to put pressure on them to respond." This definition emphasize that each person who live in democracy country have right to deliver their view and attitude towards public activities or events which related with their interest in order to get response from the government.

Interestingly, this volunteer phenomenon continues to spread to various regions, ranging from Risma Volunteer (Tri Rismaharini), or Volunteer supporters Ridwan Kamil in Bandung election 2013, as well as supporters of the governor candidate in Bangka Belitung Erzaldi Rosman who called himself "Kawan Erzaldi". The volunteer movement was declared on Saturday, June 18, 2016. According to Indostrategi Executive Director Andar Nubowo, the emergence of political volunteer movements in recent years has indeed managed to steal the public's attention. "The rise of the political volunteer movement in recent years has attracted the public's attention [accessed on March 29, 2017 from http://news.okezone.com]

The role of political volunteer might be a part of voluntary political participation in order to get new candidate who can fulfill people's aspiration. It means that political participation is the activity to convince or influence people. As said by Verba et al. (1995:38) "By political participation we refer simply to activity that has the intent or effect of influencing government action - either directly by affecting the making or implementation of public policy or indirectly by influencing the selection of people who make those policies." Therefore, political participation is to influence government action directly or indirectly.

Based on these conditions, the researcher was interested to analyze the dynamics of the public involved in political contest as political volunteers. Previous research has been conducted similarly, for example research by Yuri Alfrin Aladdin related Dynamics Role of Women in Family Politics Education for Beginner Voters to Participate in West Jakarta election 2009. The research finding explains that parents, especially mothers, are one of the most trusted sources of information for beginner voters, the role of mothers stands out when there is a voter registration process, democratic family communiation pattern, showing that parents can be role models, and the political education required not only of electoral procedures, but also aspects of regulation, rights and duties as citizens and novice voters.

Further research was conducted by Zamzam Muhammad Fuad entitled The Role of Youth Democracy Volunteers in Increasing Political Participation of the Society in 2014 Legislative Election and its Implication on the Resilience of Regional Politics (Study on Democracy Volunteers Banyumas, Central Java). The results of the study show that Youth Democracy Banyumas acts as an agent of political education and election education agents. Banyumas Democracy Volunteers also have a vital function in building political resilience in Banyumas. In other words, Banyumas Democracy Volunteers have a positive role in realizing robust political resilience in Banyumas.

Apart from the various conditions and polemic, volunteers are part of the dynamics of Indonesian politics today. Certainly, behind the political communication activities are intensively conducted by these volunteers have a variety of unique side of interest and worthy of research from academic perspective. From perspective of political communication activities, these volunteer creations may have different patterns of political communication between one another. In this research, the researcher focuses on how the dynamics of Agus - Sylvi volunteer role as political communicator at the contest of governor election of Jakarta 2017. The purpose of this research is to know and analyze how the dynamics of the role of volunteers Anies - Sandi as political communicators in preparing strategies, preparing messages and selecting political communication media to raise the political support of candidates that theystretcher on contesting governor election Jakarta 2017.

\section{METHODOLOGY}

This study used descriptive qualitative method. As submitted by Bodgan and Taylor, qualitative methodology as a research procedure that produces descriptive data in the form of written or oral words of people and behavior that can be observed. Then descriptive qualitative research is a research that collects data in the form of words, images, and not the numbers. Thus, the research report will be in the form of data citations to illustrate the presentation of the report. The data, probably from interviews, field notes, photographs, videotapes, personal documents, notes or memos, and other official documents. At the time of report writing, researchers analyzed very rich data and as far as possible in their original form (Basrowi, 2008).

By using qualitative descriptive method, the researcher explained about the dynamics of the volunteer role that occurred in the contestation of Jakarta 2017 governor election. The things that will be explored are how the communication pattern built by volunteers in mobilizing public support, communication strategy, political message delivered to the public, as well as the communication media used by volunteers on contesting the election of governor of DKI Jakarta 2017.

Data collection techniques include interviews, observation and documentation studies. Subjects in this study are the volunteers of Agus - Sylvi such as: 1) Chairman of Volunteers, 2) Volunteer Coordinator Media Field, 3) Members of 
Volunteers. Specifically, the dynamics of the role of volunteers in the contesting of Jakarta 2017 governor election, which include political communication strategy, political message, and political communication media used by volunteers to gather support on the contest of governor election of DKI Jakarta 2017. This research was done in volunteer office of Agus-Sylvi on Jl. Taruna Jaya 1, Serdang, Kemayoran Central Jakarta.

To analyze the data, researchers apply data reduction techniques, data presentation, and conclusion (verification) from Miles and Huberman. Firstly, data reduction is field data obtained through the results of observation and interview then conducted the selection process, concentration attention, abstraction and transformation rough data from the field, the second Data Presentation (Display data) is the process of presentation (display) in the form of a comprehensive description on every aspect that is researched with equipped table or chart, relation between category and similarity, last stage verification that is doing data interpretation which have been compiled. Based on these interpretations, the researchers can arrange into a conclusion, where this conclusion is the result of research that can answer research questions that have been formulated previously.

To establish the validity of the data, the researcher do triangulation of sources technique. Through triangulation of sources, researchers compare and recheck the degree of confidence of information obtained by: (1) comparing the observed data with interview data (2) comparing the consistency of the respondents' answers, ie. by comparing what the speakers said in public and what is said personally (3) comparing one's perspective, with others in his team.

\section{RESULTS AND DISCUSSION}

When reviewed comprehensively, the research findings show that the dynamics of volunteers in the contestation of Jakarta governor election 2017, broadly acts as a political communicator in charge of communicating the various vision of the candidate's mission to the public in Jakarta. In this study, researchers specifically examine how volunteers act as political communicators, what political messages are communicated to the public, and what mediums are used to convey political messages to the community.

Currently, the researcher will provide a visualization that explains the relevance between messages, media, patterns of political communication, public participation, until the end in achieving the goal of political communication. This explanation can be conveyed through the image below:

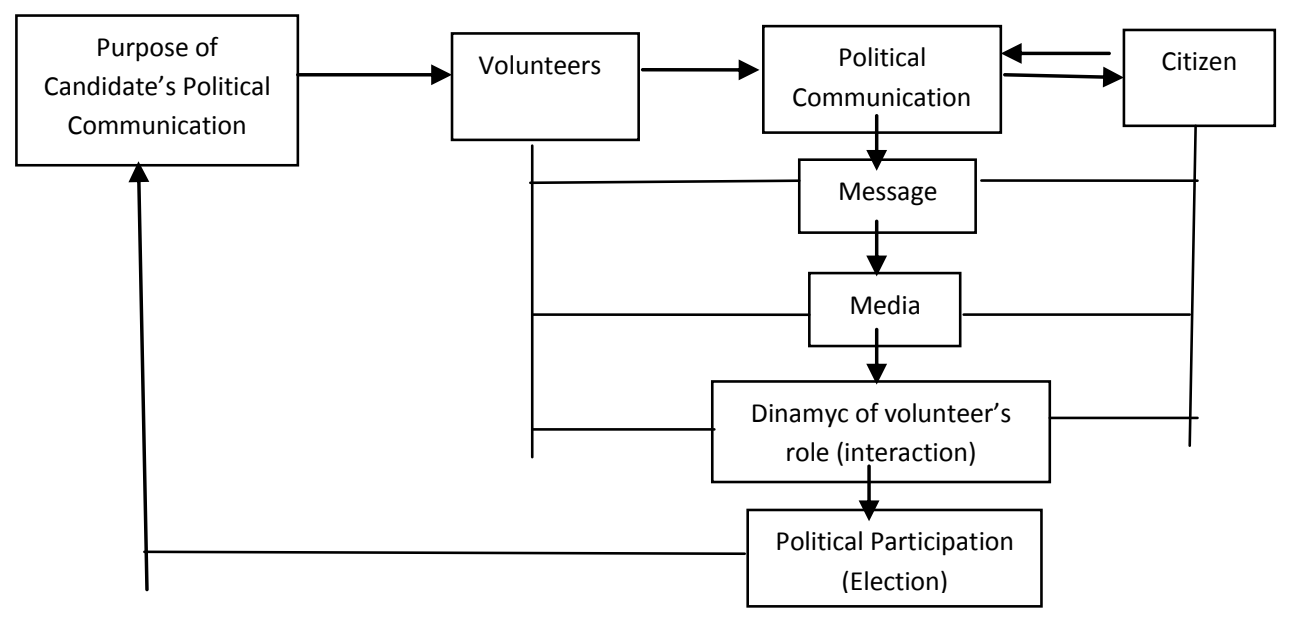

Figure 1. Conceptual Framework

The results of this research will explain how the dynamics of political communication of the volunteers on political contestation in elections DKI Jakarta 2017. The subject which concerned by researchers is how the volunteers play the role of political communicator, and how the communication patterns that occur both among volunteers with candidates, volunteers with volunteers, and volunteers with the community. In addition, researchers also try to present the exposure related to what political messages are communicated to public, and what media are selected as a medium of political communication on the contestation of Jakarta elections 2017.

\section{Volunteer as Political Communicator of the Election of Jakarta Governor 2017}

In the midst of apathy and public pessimism to engage in national politics, it was surprising when suddenly emerged the phenomenon of public participation explosion in the stage of politics. Communities are involved in various social movements such as non-abstain campaigns to be involved as political volunteers for candidates that they support, despite the presence of unscrupulous volunteers who "ask payment". Volunteers who come from various backgrounds gathered to support their candidates. Various movements have been done, such as fundraising, create a campaign message through various creative media, enter the community directly, and so forth. Beyond political parties which supporting the candidates, volunteers also have a variety of communication strategy approaches in campaigning for the credibility and accountability of their candidates. 
The volunteer movement in order to support the democracy of Jakarta elections 2017 is part of the realization of participative democracy. Sastropoetro (in Kusmanto, 2014) suggests the notion of participation is "Spontaneous involvement with awareness and responsibility for group interests to achieve common goals". In this context, the presence of volunteers is part of Jakarta's collective consciousness in participating in supporting democracy for the sake of a common goal of creating a better Jakarta.

Before further discussing about how political communication strategy conducted by Agus-Silvi's volunteers, we should understand the basic concept of political communication. Astrid (in Rabiah, 2016) suggests political communication is communication directed at achieving an influence in such a way, so that on the issues discussed by this type of communication activity can bind all its citizens through a sanction determined collectively by political institutions.

In the context of elections of DKI Jakarta 2017, the candidates are certainly competing to win the democratic contestation with various approaches of strategy and political communication respectively. Volunteers are increasingly rampant lately certainly has an important role for the candidates, where the volunteers can act as one of the political communicators who represent or connect the tongue of the candidates participating political contestation in elections DKI Jakarta 2017.

Theoretically, Anwar Arifin conveys there are three steps in shaping the political communication strategy, ie. strengthening cohesiveness and institutions, creating collectiveness with the public, building consensus (agreement) with the public. From these three steps, it is found in the volunteers' activities as political communicators in campaigning for their leading candidates.

The volunteers of Agus-Sylvi are smart to take advantage of the potentials of their candidates, such as Agus figure as a young, intelligent and not only be a rising star in the military, but also to serve the Jakarta people. In addition, the volunteers also bring Agus's figure as the son of Susilo Bambang Yudoyono, the sixth President of Indonesia. Then, Sylvi is fugured as a reliable and experienced bureaucrat. There are various kind of communication strategy approach which developed by volunteers of Agus-Sylvi. The following implementation of political communication strategies will be discussed further, such as:

Firstly, the character of SBY's figure was increasing Agus-Sylvi's popularity, since SBY has many achievements and services for Indonesia. It is proven due to SBY was elected twice through democratic mechanism (Election). This will certainly have implications both directly and indirectly on the psychological of voters, where Agus will be perceived as a person who may inherit a variety of good attitude and achievement of SBY. This condition is certainly very profitable and facilitate for volunteers in communicating and constructing the character of Agus in the eyes of the public, both personally as a clever and polite young figure, or because Agus is the son of SBY. The volunteers also communicate the character of Sylvi as a reliable, experienced, and integrity bureaucrat. In addition, the volunteers have desired to cooperate with the Democratic party as a political institution supporting Agus-Sylvi, certainly strengthening the solidity between volunteers with political parties is part of an effort to strengthen Agus-Sylvi.

This means that with the character of a politician and the stability of his political institution in society will influence in the communication. Strengthening the character and capability of composing political messages, defining methods and selecting the right political media is should be communicated to the public. To this respect, a strategy in political communication is the overall of current conditional decision depending on the action which has been taken in order to achieve future political goals. In this context, Agus-Sylvi volunteers are doing social penetration continually in order to communicate and strengthen the candidate's personality through various communication media such as banners, meetings and discussions with the community, social activities in the community, and so on. Through this research, researcher identify that the figure of SBY is one factor that is enough to boost the popularity of Agus-Sylvi. This is reinforced by the statement of Vice Chairman of the Democratic Party, Syarief Hasan who believes the popularity of Susilo Bambang Yudhoyono (SBY) will also boost the popularity of his son, Agus Harimurti Yudhoyono [online] KOMPAS.com accessed on 4/10/2017.

Secondly, in order to strengthening cohesiveness and institutionality, Agus-Sylvi volunteers also seek to build relationship with Jakarta citizen. The volunteers strive to create collectiveness through various activities such as work devotion, social service, periodic conversations in the coffee shop, etc. This kind of approach is part of the effort to make relationship with the public, thus the public has emotional relationship with the volunteers and candidates. The strategy of Agus-Sylvi volunteers needs to be appreciated, in the political context to achieve the goal of political communication, it is necessary to create relationship between politicians and the public (the people) by organizing and preparing homophily messages to the public. It is necessary for political communication to empathize. Homophily atmosphere that must be created is the equation of language (symbol of communication), fashion equations, equality of interests with the audience and norms within the group is located. Various activities such as work of devotion, social service, formal / informal forums, conversations in coffee shops, etc. are channels to communicate the various vision and mission messages of Agus-Sylvi's through their volunteers. Obviously, this kind of public participation needs to be improved in order to realize the quality of participatory democracy.

Thirdly, another thing to do in a political communication strategy is to build consensus with the public or constituents. Building a consensus between politicians in one political party and between politicians and different parties. The third strategic should be done to achieve the goal of political communication, which is building a consensus between 
politicians in a political party and between politicians with different parties. Agus-Sylvi launches "one billion rupiah" for one group district is a consensus with the community if they elected as governor of Jakarta. Through the program, AgusSylvi volunteers communicate that the program is part of the candidate's commitment to empower communities in big cities like Jakarta.

From above explanation, it can be seen that the role of Agus-Sylvi volunteer as political communicator has adapted the approach of political communication strategy from Anwar Arifin (2011) which states that there are three ways in political communication strategy, including strengthening of cohesion and institutional, creating togetherness, and building consensus. Principally, political communication needs to be connected between the vision and mission of the candidate, the supporting parties, volunteers and other sympathizers.

In this context the homophily theory is very important to be implemented. According to Arifin, homophily theory is the individual's ability to create togetherness, both physically and mentally. Homophily can create social relationship, intensive and effective communication which is very important to be implemented (Carundeng, et al 2016). To this respect, the volunteers also play a role as political communicator which aimed at delivering the vision and mission of the mission of Agus-Sylvi, constructing and strengthening Agus-Sylvi's figures, building closeness with the public, delivering Agus-Sylvi consensus to the community related to community empowerment program through giving money with amount of one billion per one group district. In performing its role as political communicator, volunteers approach the community through various ways such as engaging in formal and informal activities, including involvement in work activities, social service, formal or informal forums, conversations in coffee shops, and so on.

The inclusion of volunteers in supporting candidate both at the level of local elections until presidential elections, certainly shows a positive climate for national politics. These volunteers can indirectly accelerate the achievement of political goals. Theoretically, the purpose of political communication is to create a political image, public opinion, encourage political participation, win elections, and influence political policy of the state or public policy (Arifin, 2011). In this context, volunteers have an important role in achieving the political communication goals of candidate Agus-Sylvi.

First, the volunteers have a role to communicate the various advantages of candidates to the public. If this is done properly, then the political image of Agus-Sylvi can be formed based on information submitted by volunteers, either directly or through political media, including social media and mass media. The way volunteers shaped the political image by exposing the vision, mission, work program, charisma of the candidate, and etc. Political image is constructed through meaningful perceptions of political phenomena and then expresses that meaning through beliefs, values, and expectations in the form of personal opinions which can be developed into public opinion. In this context, various efforts have been made by volunteers in shaping a good political image for Agus-Sylvi, but the feelings and perceptions of the public can not be forced. Thus, the team volunteers need to realize that their candidate has not been able to steal citizen's willing in order to choose their candidates.

Second, the volunteers try to create a good and conducive public opinion toward Agus-Sylvi. Public opinion is not limited to the effects of political communication by candidates or volunteers, but also feedback from audiences to candidates or to volunteers. It is important for volunteers to get positive public opinion such as opinions, attitudes, feelings, stance and expectations of the Jakarta citizen. Obviously, all volunteers expect the creation of positive public opinion on their candidate. Public opinion which try to be strengthened from Agus-Sylvi is a young figure for Agus and experienced for Sylvi who have professionalism, integrity and commitment to Jakarta.

Third, the purpose of the next political communication is the increase of political participation in the Jakarta election. The existence of the phenomenon of explosive political participation in the form of the rise of volunteers is one indicator of the realization of the purpose of political communication. In addition, the volunteers also one of the mobilizer of democracy. Given the current bad impression of national politics, people are less likely to be involved and participate in practical politics. The presence of the volunteers is certainly a good movement for the portrait of our politics, and hopefully these volunteers can spread the spirit of political participation to other communities. In this context, the volunteer of Agus-Sylvi try to communicate about their optimism to the community that the presence of Agus-Sylvi is the answer to address the problem of the politics in Indonesia. Regardless of Agus-Sylvi was not win, the existence of the volunteers has a positive impact on increasing public participation in the Election of Jakarta.

Finally, the form of public participation in political activity is one of them is to follow the election. Elections is one of the most important goals of political communication and candindate expect to be won. Success or failure of effective political communication is measured by the number of votes obtained through the elections. The winning for the candidate is the result of political communication which conducted during the campaign, and certainly not the result of intimidation or money politics (money politics) systematically, both individual and group to the public. Various approaches to political communication have been done, but in democracy it is people who becomes the determinant. Although Agus-Sylvi was lose, the presence of volunteers is important as supporters for the mobilization of some communities to choose Agus-Sylvi.

From the analysis, we understand that the volunteerism in the election of the Head of Region until the election of the President is part of the journey of democracy that should be appreciated. The presence of volunteers helps the candidates to strengthen their figure and popularity, become a bridge with the community, strengthen relationship of both candidates with the community, and strengthen relationship between supporters (volunteers, sympathizers, parties, 
community), then volunteers as well as representatives in delivering promise and commitment (consensus) with the public

\section{Message Analysis, Media, and Communication Pattern of Volunteer Politics at Jakarta Election 2017}

As mentioned earlier that in communication the most important thing besides the communicator is the message. Effendy (2001) further explains the purpose of mind-shaped messages can be the ideas, information, opinions, feelings, and others that appear in the minds of communicators. In the process of political communication, political messages are the most important component. Referring to the definition of political communication, the political message is a message carried by political communicators, both in the form of ideas, thoughts, feelings, attitudes, and behavior about politics that influence political communication. In the context of political communication, the political message is a message carried by political communicators, whether in the form of ideas, thoughts, feelings, attitudes, and behavior about politics that influencing political constituents or society (Fadillah, Farihanto, \& Dahlan, 2017).

In this context, Agus-Sylvi volunteers have been engaged in political communication activities that are involved in formulating and communicating the political messages of the candidates, through various channels of communication, aimed at influencing, building, and shaping public opinion. The various vision, mission, work programs, ideas and other important things that Agus-Sylvi delivered through the volunteers is a political message. Political communication usually attempts to influence major interests such as public political decisions, receive the power by trying to place the candidate to be elected and ultimately become head of the region.

The political message delivered by Agus-Sylvi volunteers is a representation of the candidate's vision and mission. The vision of Agus-Sylvi is making Jakarta to be more developed, safe, fair and prosperous in 2022. Then the vision is derived into a mission that is a) to realizing the development of Jakarta, b) realizing a safety of Jakarta, c) realizing a fairness of Jakarta, d) realizing a prosperous of Jakarta, e) realizing "Green Jakarta" into better environment, f) realizing a comfortable and dignified Jakarta.

The efforts to deliver political message of Agus-Sylvi have been done by the volunteers with inserting political messages through various social activities. It was supported by the media both conventional media and digital media. Social activity is one medium to communicate various vision and mission, work program, commitment, and also candidate's strength. The delivery of political messages is done either through direct or non-face-to-face communication. Communication is done directly to the community usually through social service and chatting in the coffee shop. In the middle of the conversation, volunteers inserted a variety of both formal and informal chats to the community.

Conventional communication media are also used by volunteers to communicate and reinforce messages that have been delivered either directly or indirectly. Media which used include banners, calendars and t-shirts. The media are used as a medium of political communication, in which written political messages both text and visual. With the media it is expected that people can know, interest, and determine to choose Agus-Sylvi. Obviously, the media is very helpful to inform the various vision and mission of the candidate, given the communication made by volunteers would certainly not be able to touch the whole community.

In addition to conventional media, Agus-Sylvi volunteers also use digital media as a media of political communication between volunteers, as well as volunteers with the community. According to Chavez, Stietglitz, and Dang Xuan that the development of communication technology has penetrated the lives of mankind. One form of communication technology development is a new media which then rising into social media. The presence of social media also influences the political sphere. Studies in the United States show social media is an effective campaign tool. Before the era of social media, politicians in US already used the internet for media campaigning (Anshari, 2013). This condition did not escape from the couple Agus-Sylvi and Volunteers to utilize social media as a media of campaign.

The digital media used by Agus-Sylvi is social media and WhatsApp as a medium of information for group to group. The presence of these media certainly provide convenience for the volunteers in coordinating and disseminating various information quickly, practically and inexpensively. The volunteers realized that the direct communication dimensions of offline and online communication should be done simultaneously, considering that nowadays people are already technologically literate and accustomed to using the new media in their daily life.

Social media, such as facebook, at first, tends to be related to the issue of friendship. However, at this time, began to touch on the political realm of government or state power. Ruben (Budiyono, 2016) affirms that the development of communication technology has a good effect on the political process. In fact, the progress of digital communication with e-mail will lead to a new spirit of democracy. In the context of elections Jakarta Governor 2017, all candidates have been very good at using social media in attracting people.

To optimize community engagement and participation in supporting Agus-Sylvi's, the volunteers were helped by the android application of Agus-Sylvi's successful team, MataHati application. This app launched is an effort to anticipate the occurrence of cheating during the elections. Alliance is IT based that can be used in android smartphone. For volunteers, the application can be downloaded at https://www.jagaagussylvi.com/relawan-jas. Then, in order to increase public participation, such as sympathizers, supporters and the public can generally download at https://play.google.com/store/apps/details?id=app.jagaagussylvi.

The goal of friends of volunteers, supporters, sympathizers and all citizens of Jakarta using applications has purposes to report the practice of fraud before voting and when voting, the identity will be kept confidential. Then, 
anyone who installs and uses this application can assist as a witness at the election booth [online]. http://www.tribunnews.com/ accessed on February 23, 2017.

The various communication media used by Agus-Sylvi's partner is supported by the campaign team and the volunteers are part of a political endeavor in political contestation. Through such communication media, it is expected that knowledge transfer can be delivered both rationally and emotionally. The rationale is how the communication medium used to deliver information about explanations and reasons why people should believe and understand the vision and mission, work program and candidate's integrity. Then on the emotional aspect, the political communication media used is expected to develop closeness, empathy, and trust to the candidate. Communications media can present information both descriptive and visual in an interesting and emotional community. The use of these various media is expected to strengthen the emotional relationship with the community and further strengthen the choice of society to the couple Agus-Sylvi.

Another interesting thing that happened in the dynamics of political communication of the volunteers on the political contestation of Jakarta elections 2017 is to understand how the pattern of communication that occurs among the volunteers. This is interesting because the volunteers are a group of people who are members of a voluntary and unpaid team to be actively involved in supporting the leading candidates. They are ordinary citizens who may not be affiliated with any political party and have no practical political interest whatsoever. Ideally it is this concept that we need to understand, regardless of the level of implementation may be found unscrupulous volunteers who do not have these criteria.

Volunteers according to Slamet (Thistle and Halimah, 2012) are unpaid people who providing the time to achieve organizational goals, with substantial or limited responsibilities, with little or no special training, but can be accompanied by highly intensive training in a particular field, to work volunteer, to help professionals. Furthermore, Thistle and Halimat (2012) emphasize that volunteers are citizens who are sincerely without differentiating the degree, sex and social status with their devoted self without expecting any benefit (either in the form of reward or career). Anyone can be a volunteer, as long as they have spirit of resistance. Volunteers are not dependent on the origin of a particular community group or region because volunteers do not struggle for the interests of a particular group, religion or region.

Analysis of communication patterns that will be exposed is how the pattern of communication that occurs between volunteers with partner Agus-Sylvi, communication patterns between volunteers, and communication patterns between volunteers with the community. In this research, the researcher find out in general, there are two communication activities that are internal coordination activity of volunteer and candidate (applying vertical and horizontal communication pattern), and activity of message transfer from volunteer to society (applying formal and informal communication pattern).

Vertical communication is applied when volunteers receive transfer of information about the mission vision and work program which presented by the candidate. Volunteers in this context are limited to receiving the message. Rationally, it is certainly impossible to be a volunteer if volunteer does not agree on the candidate's vision mission and work program. In addition, the vision mission and work programs are part of the candidate's commitment formulated through the mapping of the condition of the Jakarta community based on candidate analysis. In this context, volunteers play a role to communicate the vision mission and the work program to the community. Main things related to what political messages should be communicated to the community are referring to the candidate's vision mission and work program, but the volunteers are given space to elaborate and creative as long as they are related with the vision mission and work program that has been established.

Horizontal communication is applied when volunteers coordinate both with candidates and between volunteers on the formulation of campaign strategies to the community. For example, related to communication strategy planning, how to package political messages, choose political media, and identify characteristics of society. Through this horizontal communication pattern, volunteers position themselves parallel to one another. In addition, this type of communication allows for fluid and dialogical communication. Although in this horizontal communication volunteers tend to be more flexible, but the various programs that are designed must necessarily be in line with the vision of the mission and work program that has been determined candidates.

When the process of coordination has passed, the next step is how the volunteers should communicate the political message to the community properly and supported by effective and efficient communication media. Researcher identify at least two patterns of communication applied by volunteers in delivering their political messages to the community, including the formal and informal communication patterns. A formal pattern of communication takes place when people are invited to the discussions or meetings in a planned way. At the meeting, the communication process carried out more serious and systematically, although it still dialogical. At the meeting, volunteers usually expose various vision and mission, work program, commitment of candidate, and also candidate's superiority to society. This formal communication is conducted as an effort to build trust and provide a rational understanding, related to the reasons why people should choose candidates.

To attract the hearts of the people of Jakarta, the volunteers must be good at looking for various opportunities through humanist and sympathetic approach. Various rational explanations of the candidate's superiority will not be enough to win the public's sympathy. Beside the aspect of rationality, the community also needs psychological proximity with the candidate. This is where the role of candidates is required to communicate the message candidates in a 
sympathetic and impressive ways, so as to touch the feelings and emotions of the people of Jakarta. Various discussions at the coffee shop, talkshows during work, and other informal activities were conducted by volunteers in order to build an emotional relationship between the candidates and Jakarta citizen.

\section{CONCLUSIONS AND RECOMMENDATIONS}

Based on the results of research and analysis, in regards with the dynamics of the role of volunteers as political communicators at the election of Governor of DKI Jakarta 2017, it can be drawn the conclusion as follows:

1. The political communication strategy applied by the volunteers Agus-Sylvi prioritizes approaches such as: a) Creating collectiveness, b) Making consensus with the community, and c) Rising the character of SBY as part of strengthening the power of Agus.

2. The political communication messages which built by Agus-Sylvi's volunteers is a message that put forward the rational and emotional aspects. Rational messages are messages that refer to the vision of the candidate's mission and working program. Then, to reinforce the message of a rational nature, Agus-Sylvi's volunteers also build communications that are family centered, sympathetic and dialogical. This is part of the political communication effort that is carried out as an effort to attract the emotional of DKI Jakarta's citizens.

3. Campaigns which conducted by Agus-Sylvi's volunteers through greeting the citizens, such as meetings and dialogues, work devotion, social service, and casual chat. Communication media which used was conventional communication media such as banners, calendars, t-shirts. Then digital media such as WhatsApp, website and application "MataHati". "MataHati" application is an application used to involve the public in monitoring the potential for the violation during the elections.

4. In regards with communication pattern of the volunteers, there are two communication activities namely the internal coordination of volunteers and candidates (applying vertical and horizontal communication patterns), and the activity of message transfer from volunteers to the community (applying formal and informal communication pattern).

The results show the implementation of volunteer for their political communication program is good enough, but there are still some things that can be recommended for future improvement. Here are some suggestions from the research:

1. Political communication strategy should strengthen the candidacy of governor candidate. Thus, the impression menggompleng figure or a certain figure is not so visible. Consensus and political contracts should be more rational and participatory.

2. Existency of Agus-Sylvi with Jakarta citizens must strengthen through various programs, not merely ceremonial activities but should prioritize to the community development programs, such as trainings and so forth. In addition, candidates should prepare well in advance, so the candidates are not impressed suddenly and are much better known and close to the community.

3. The spread of volunteers in the community can be more sporadic. Several points of location, the existence of the volunteers have not been optimal in campaigning partner Agus-Sylvi. Thus, the spread of political campaigns will spread widely.

\section{ACKNOWLEDGEMENTS}

Researcher is greatful to all people who have contributed in support of the completion of this paper. Firstly, the authors owe a great gratitude to Mercu Buana University that give support to the researcher. Secondly, researcher would like to express gratitude to the volunteers of Agus-Sylvi who have the willing to help this research.

\section{REFERENCES}

- Aladdin, Alfrin Yuri. Dinamika Peran Perempuan Dalam Pendidikan Politik Keluarga Bagi Pemilih Pemula Untuk Berpartisipasi Pada Pemilu 2009 Di Jakarta Barat. Jurnal Visi Komunikasi/Volume XII, No. 02, November 2013.

- Anshari, Faridhian. Komunikasi Politik di Era Media Sosial. Jurnal komunikasi, ISSN 1907-898X Volume 8, Nomor 1, Oktober 2013.

- Anwar Arifin. 2011. Komunikasi Politik: Filsafat-Paradigma-Teori-Tujuan-Strategi-dan Komunikasi Politik Indonesia. Yogyakarta: Graha Ilmu

- Budiyono. Media Sosial dan Komunikasi Politik: Media Sosial sebagai Komunikasi Politik Menjelang PILKADA DKI JAKARTA 2017. Jurnal Komunikasi P-ISSN: 1907-898X, E-ISSN: 2548-7647 Volume 11, Nomor 1, Oktober 2016

- $\quad$ Basrowi. 2008. Memahami Penelitian Kualitatif. Jakarta: PT. Rineka Cipta.

- Carundeng R. Kenny, Paputungan, Ridwan, dan Tangkudung J.P.M. Pola Komunikasi Politik Anggota DPRD Kota Kotamobagu. e-journal “Acta Diurna” Volume V. No.2. Tahun 2016.

- $\quad$ Dahrendorf R (2003). The Challenge for Democracy. Journal of Democracy. 14 (4). 
- EACEA (Education, Audiovisual and Culture Executive Agency) (2012). Political participation and EU citizenship: Perceptions and behaviors of young people. Evidence from Eurobarometer surveys. European Commission.

- Halimah, Nur Siti \& Widuri, Listyanti Erlina .Vicarious Trauma Pada Relawan Bencana Alam. Humanitas, Vol. IX No.1 Januari 2012.

- Haste, H. \& Hogan, A. (2006). Beyond conventional civic participation, beyond the moralpolitical divide: Young people and contemporary debates about citizenship. Journal of Moral Education, 35(4), 473-493.

- Huntington, S. P. \& Nelson, J. M. (1976) No Easy Choice: Political Participation in Developing Countries. Cambridge, Mass.: Harvard University Press

- Fadillah, O. D., Farihanto, M. A. M. N., \& Dahlan, U. A. (2017). KOMUNIKASI POLITIK ANTAR KOALISI PARLEMEN DI DPR RI B . Komunikasi Politik, 111-119.

- Fuad, Muhammad Z. Peran Pemuda Relawan Demokrasi Dalam Meningkatkan Partisipasi Politik Masyarakat Pada Pemilihan Umum Legislatif Tahun 2014 Dan Implikasinya Terhadap Ketahanan Politik Wilayah (Studi Pada Relawan Demokrasi Banyumas, Jawa Tengah). Jurnal Ketahanan Nasional, XXI (1), April 2015: 23-33.

- Jailani. Sistem Demokrasi Di Indonesia Ditinjau Dari Sudut Hukum Ketatanegaraan. Jurnal Inovatif, Volume VIII Nomor I Januari 2015.

- Kusmanto, Heri. Partisipasi Masyarakat dalam Demokasi Politik. Jurnal Ilmu Pemerintahan dan Sosial Politik UMA 2 (1) (2014): 78-90

- Rabiah, Sitti. Ragam Bahasa Indonesia Dalam Komunikasi Politik. The POLITICS: Jurnal Magister Ilmu Politik Universitas Hasanuddin. Vol. 2 No. 1, Jan 2016 | P-ISSN: 2407-9138.

- Verba, S., Schlozman, K. L., \& Brady, H. (1995) Voice and Equality: Civic Voluntarism in American Politics. Cambridge, Mass.: Cambridge University Press.

\section{Online References:}

- $\quad$ www.republika.co.id/berita/koran/teraju/16/03/29/o4srwl20-relawan-di-pusaran-politik

- https://news.detik.com/berita/d-3314983/ini-visi-misi-agus-sylviana-untuk-dki-jakarta

- http://www.tribunnews.com/metropolitan/2017/01/17/cegah-kecurangan-duet-agus-sylvi-luncurkan-aplikasi-itdi-android

- https://news.okezone.com/read/2016/06/18/340/1418552/fenomena-relawan-wujud-meningkatnya-partisipasipolitik-masyarakat 